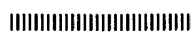

論文

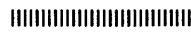

\title{
ナイロン66繊維の超分子構造の経時变化
}

\begin{tabular}{|c|c|c|c|c|}
\hline 旭化成工業(侏) & 岩 & 田 & 道 & 隆 \\
\hline " & 牧 & 野 & 広 & 行. \\
\hline " & 上 & 出 & 健 & 二（会員） \\
\hline " & 真 & 鍋 & 征 & 一 (会員) \\
\hline
\end{tabular}

\section{Change in Supermolecular Structure of Nylon 66 Fiber with Time Elapsed}

\author{
Michitaka Iwata,Hiroyuki Makino,Kenji Kamide"and Sei-ichi Manabe"
}

*Fundamental Research Laboratory of Natural \& Synthetic Polymers, Asahi Chemical Industry Co.Ltd.

\begin{abstract}
An attempt was made to inves tigate the change in supermolecular structre of nylon 66 fiber with elapse time. A nylon 66 fiber was kept in the room controlled isothermally or in the room without the control under free of tension for about 1000 days.

The change in supermolecular structure of the fiber was evaluated by wide angle X-ray diffraction,interference microscopy and dynamic viscoelastic properties. With an increase in elapse time,the perfection of crystal increased,and the crystal orientation decreased. In the amorphous region,molecular chains were strained,and relaxed at a later time.Moreover at 900 days later,the domain,in which the molecular chains were densely packed, war in the amorphous region.these tendencies were more emphasised in the cose of leaving in to room with out themal control.

(Received July 17,1995)

(Accepted for Publication November 17,1995)

\section{適 要}

ナイロン 66 繊維の放置過程における超分子構造，特に結晶および無定型領域内部の分子鎖の凝集構造の経時变化について検 討した. ナイロン66䋞維は室内および室外に約1000日放置した。その間の超分子構造の変化は広角 X 線回折, 干渉顕微鏡, 動的 粘弾性によって評価した。

その結果，放置時間の経過に伴ってナイロン66繊維の結晶領域においては，結晶は大きくなり，その完全度も高くなる．また 配向度は小さくなる，無定型領域においては，放置時間の経過に伴って，分子鎖はいったん緊張状態になり，その後緩和する. さらに900日を経過すると分子鎖の充填状態の密な部分が新たに出現する。これらの変化は室外放置試料において著しい.
\end{abstract}

(平成 7 年 7 月 17 日受理)

（平成 7 年11月17日審查終了）

\section{1. 緒 言}

溶融紡糸法を利用して, 紡糸, 延伸, 巻取された フィラメント原糸の構造安定性は, 捲縮付与, 染色 工程等の原糸の後加工性に大きな影響を与える. 特 に,ナイロン66（ポリへキサメチレンアジパミド） 繊維原糸の場合, 引張破断伸度, ヤング率などが経
時的に著しく変化することが，緎維製造現場におい て経験的に知られている，そのために紡糸巻取後の ナイロン66繊維は，通常一定期間調湿された条件下 で放縮する．放縮あるいは放置過程中での繊維物性 の変化は, 緘維の超分子構造の変化に原因すると考 えられる.

本論文では，室内，または室外に約 3 年間放置し 
た場合のナイロン66繊維の超分子構造, 特に結晶お よび無定型領域内部の分子鎖の凝集構造の経時変化 について明らかにすることを試みた。

\section{2. 実 験}

\section{1 試 料}

既報 12)で用いたナイロン 66 チップ（末端 $\mathrm{NH}_{2}$ ； $52 \mathrm{meq} / \mathrm{kg}$, 末端 $\mathrm{COOH} ; 70 \mathrm{mq} / \mathrm{kg}$, 粘度平均分 子料 $\mathrm{Mv} ; 1.8 \times 10^{4}$ ) を溶融紡系 (溶融温度 $298^{\circ} \mathrm{C}$, 紡 系速度 $607 \mathrm{~m} / \mathrm{min}$, 延伸比 3.9 , 延伸速度 $800 \mathrm{~m} /$ min) し, 70 d/24f のナイロン66絾維を作製した。

\section{2 試料放置条件}

上記ナイロン 66 繊維を以下の条件下に放置した。

1) 恒温室内放置

平均 $20^{\circ} \mathrm{C}$ で制御され, 1 日内での変動温度幅 $5^{\circ} \mathrm{C}$, 年間温度変動範囲 $15 \sim 30^{\circ} \mathrm{C}$, 年間湿度変動範囲 40 ～60\%RH，試料はすべて無緊張で自動で吊るされ た状態で放置された. 日光の照射はないが室内照明 を 1 日当たり, 平均 $12 \mathrm{hr}$ 受けた。

2) 恒温室外放置

1)の恒温室の外室内に放置した. 外気温の变動と ともに変動する. 1 日内での変動温度幅 $10^{\circ} \mathrm{C}$, 年間 温度変動範囲 $0 \sim 35^{\circ} \mathrm{C}$, 年間湿度变動範囲 $30 \sim 90 \%$ $\mathrm{RH}$, 試料はすべて無緊張で自重で吊るされた状態 で放置された，日光の照射はないが，室内照明を 1 日当たり平均 $6 \mathrm{hr}$ 受けた.

なお，この放置期間中の外気温は大阪府気象月報 （昭和55年～昭和58年) 枚方観測所（地点番号62046） によると日変動で約 $15^{\circ} \mathrm{C}$, 年間を通じて最高気温約 $38^{\circ} \mathrm{C}$ 最低気温 $-6^{\circ} \mathrm{C}$ 変動を観測された. 上記の 放置条件ではいずれも外気温の変動幅より小さい. 以下 1）の試料を室内放置試料，2）の試料を室外放 置試料と略称する。これらの試料は1980年 7 月 26 日 紡糸し， 7 月28日延撚した。その試料を1980年10月 18 日から約 3 年間放置した。

\section{3 測定方法}

\section{A. X 線回折}

$\mathrm{X}$ 線回折装置として, 理学電機工業(㑣)製 $\mathrm{RU}$ $200 \mathrm{PL}(\mathrm{CuK} \alpha$ 線 $(\lambda=0.1542 \mathrm{~nm})$ を用い, 計数管に はシンチレーションカウンター（SC），計数部には 波高分析器（PHA）を用いた．試料を厚さ $0.5 \mathrm{~mm}$ ぐらいになるようにサンプルホルダーにセットし,
対称反射法で, 試料を X 線回折面に対して垂直に 配置し, 赤道方向の X 回折強度曲線を測定した。 そ の曲線から微結晶の大きさ $(A C S)$, 結晶完全度 $(C P I)$ を算出した. また赤道方向の $\mathrm{X}$ 線回折強度曲 線から得られた回折面に注目して, 対称透過法で, 試料を X 線回折面に対して垂直に回転させ, 方位 角方向の強度曲線を測定した. 以下にそれぞれの解 析方法を示す。

(1)微結晶の大きさ (ACS ( $\mathrm{nm})$ )

赤道方向の $\mathrm{X}$ 線回折強度曲線の回折角が $2 \theta=7^{\circ}$ から $35^{\circ}$ の間を直線で結びベースラインとした，回 折ピークの頂点からベースラインの中点での半価幅 をScherrerの(1)式に代入して，微結晶のと大きさ を求めた.

$$
\begin{gathered}
A C S(\mathrm{~nm})=\lambda / \beta \cdot \cos \theta \\
\beta=\sqrt{\mathrm{B}^{2}-\mathrm{b}^{2}} \text { なる式で表される. }
\end{gathered}
$$

ここで, $\lambda$ はX 線の波長, $\beta$ は補正された半価幅 で, $B$ は測定された半価幅, $b$ はブロードニング定 数で, $\mathrm{Si}$ 単結晶の (111) 面の反射のピーク幅 $\left(0.2^{\circ}\right)$ である.

(2)結晶完全度 (CPI（\%))

次式 より結晶完全度 (\%) を求めた.

$$
C P I(\%)=(\{d(100) /\{d(010)+d(110)\}-1] /
$$

$$
0.18) \times 100 \quad(2)
$$

$d(\mathrm{hkl})$ は (hkl) 反射の面間隔で, CPI の值が 100 に近い程結晶の完全性が高い。

(3)結晶配向度 (CO (\%))

対称透過法で得られた方位角方向の X 線回折強 度曲線から $\pm 180^{\circ}$ の方位角方向の $\mathrm{X}$ 線回折強度の 平均を取り, 水平線を引き基線とする. ヒークの頂 点から基線に垂直の垂線を引き,この垂線の 1/2 の 点より水平線を引く, この水平線と $\mathrm{X}$ 線回折強度 曲線の交点間の距離を測定し,この值を角度 $\left(^{\circ}\right)$ に 換算した值を配向角 $\mathrm{H}^{\circ}$ とす。. そして結晶配向度 は次式 ${ }^{4)}$ で求めた。

$$
\mathrm{CO}(\%)=\left\{\left(180-\mathrm{H}^{\circ}\right) / 180\right\} \times 100
$$

\section{B. 熱特性}

ナイロン66の融点の測定には, Perkin-Elmer 社 製 DSC $-1 \mathrm{~b}$ 型を使用した。試料約 $1.3 \mathrm{mg}$ を窒素ガ 霛囲気下で, $165^{\circ} \mathrm{C}$ から昇温速度 $2.5^{\circ} \mathrm{C} / \mathrm{min}$, $20^{\circ} \mathrm{C} / \min$ および $80^{\circ} \mathrm{C} / \min$ の 3 水準で昇温し, 融解曲線を測定した。融解曲線より結晶の部分融解 の開始温度 $\mathrm{Tm}_{1}$, 結晶の融解ピーク温度 $\mathrm{Tm}_{2}$, 測定 中に試料が熱処理を受け不安定な構造が結晶化した ために生じた結晶の融解に基づくと考えられる第 2 
の吸熱ピーク温度 $\mathrm{Tm}_{2}^{\prime}$ 結晶の融解終了温度 $\mathrm{Tm}_{3}$ を決定した。

\section{C. 動的粘弾性温度特性}

動的粘弾性温度特性は, 東洋ボールドウイン製 Rheovibron DDV- IIC 型を使用した。試料をあら かじめ 48 時間以上乾燥空気中に $\left(0^{\circ} \mathrm{C}, \mathrm{RH}=0 \%\right)$ に保存し， 試料約 $1 \sim 2 \mathrm{mg}$ を平均昇温速度約 $7^{\circ} \mathrm{C} /$ $\min$, 乾燥空気中, 測定周波数 $110 \mathrm{~Hz}$ の条件下で 力学的損失正接 $(\tan \delta)$ - 温度 $(T)$ 曲線抒よび動的 弾性率（E） を測定した。 また $\tan \delta$ - $T$ 曲線から $\tan \delta$ のピーク高さ $(\tan \delta)_{\max }$ および $\tan \delta$ のピーク 温度 $\mathrm{T}_{\max }\left({ }^{\circ} \mathrm{C}\right)$ を求めた。

\section{D. 干渉顕微鏡}

Carl Zeiss Jena 社製干渉顕微鏡インターファコ を用いた。 波長 $549 \mathrm{~nm}$ の光を繊維の側面から入射 した場合の繊維軸に平行および垂直方法に振動面を 持つ偏光による干渉縞を撮影した。 干渉縞を撮影す る際の試料の浸液として, $n \|$ の測定にはヨウ化メチ レンと丁字油の混合物を $n \perp$ の測定にはオリーブ油 と桂皮油の混合物を用いた.

\section{3. 結果および考察}

図 1 に室内放置試料の動的粘弾性温度特性, 熱特 性およびX X 線回折測定結果を示す。横軸は経時日 数, 縦軸は $\tan \delta-T$ 曲線から得た $20^{\circ} \mathrm{C}$ における $\tan \delta_{20}$, ピーク温度 $T_{\max }$ とピーク值 $(\tan \delta)_{\max }, D S C$ から得た融解ピーク温度 $\mathrm{Tm}_{2}, \mathrm{X}$ 線回折から得た $C P I$ を示す. 0 25 日の間では, $T_{\max }(\tan \delta)_{\max }, T \mathrm{~m}_{2}$ などはほとんど変化しないが, $\tan \delta_{20}$ は単調に減少 し，CPI は経時的に增大する.

図 2 に結晶完全度 $C P I$, 図 3 に微結晶の大きさ $A C S$ の約1000日間の経時変化を示す. 図中の○は 室内放置試料, ○は室外放置試料である. CPI は 0 〜20日までは室内および室外放置試料ともに単調に 増加する. 特に室外放置した場合の方が室内放置に 比べて増加率は大きい，20～100日頃の経時変化が 小さくなるのは, 冬期のデータで, 温度が低いため であると考えられる．また $A C S$ あ CPI と同様の変 化を示す。

図 4 に室外放置試料の X 線回折強度曲線の経時 変化を示す. 経時日数の増加に伴って安定な結晶構 造 $\left(\alpha\right.$ 型, $\beta$ 型) を持ったナイロン $66^{5)}$ では出現しな い回折角 $2 \theta=11^{\circ}$ のピーク強度が増加する.

図 5 に干渉顕微鏡写真の干渉縞の室外放置試料の 経時変化を示す. 図中の数字は経時日数を示す.

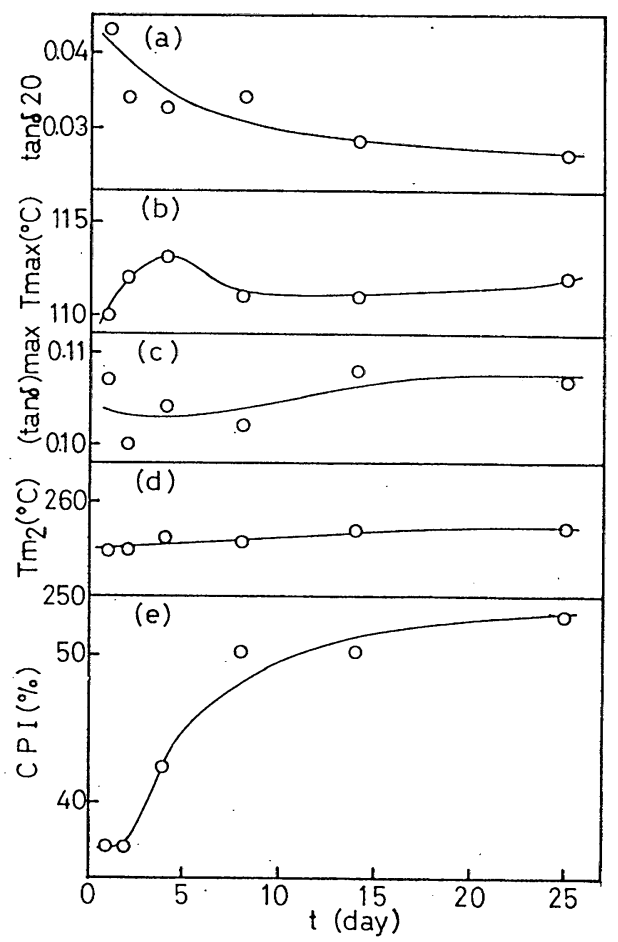

図 1 室内放置試料の $\tan \delta_{20}(\mathrm{a}), T_{\text {max }}(\mathrm{b}),(\tan \delta)_{\text {max }}(\mathrm{c})$, $\mathrm{Tm}_{2}(\mathrm{~d}), C P I(e)$ の経時日数 $t$ 依存性

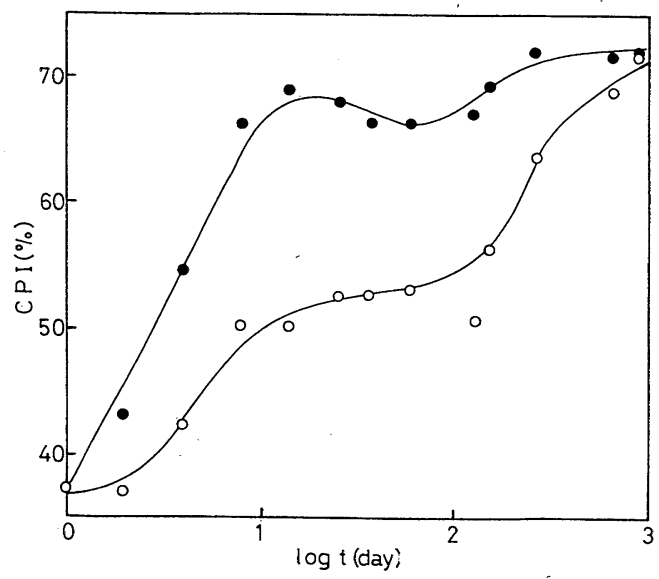

図 2 結晶完全度 $C P I$ の経時日数 $\mathrm{t}$ 依存性 $\bigcirc$ : 室内放置試料

: 室外放置試料

$n \|, n \perp$ はそれぞれ繊維軸に対して平行および垂直 方向の屈折率である。 また十の記号は干渉縞が左か ら右にずれると屈折率が高くなることを示す．図よ り経時日数とともに $n \|$ および $n \perp$ 方向の屈折率は 増大するが, $n \| よ り ~ n \perp$ 方向の屈折率の増加が大き く, そのために複屈折率 $\Delta n$ は減少する.すなわち 分子鎖の配向度は経時的に減少する.なお X 線回 


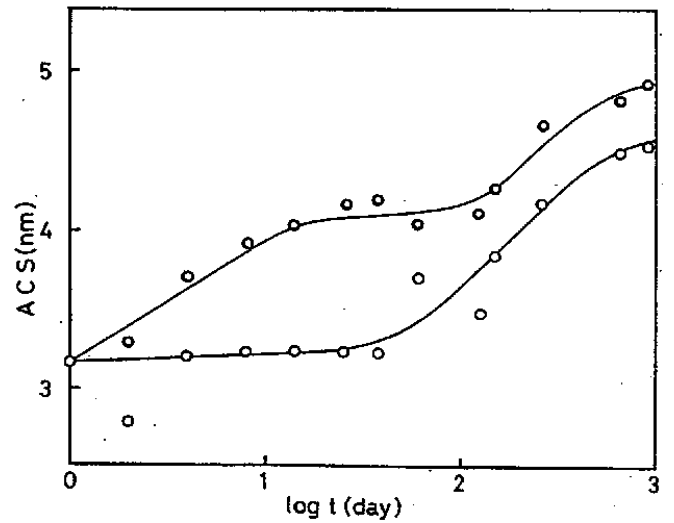

図 3 微結晶の大きさ $A C S$ の経時日数 $\mathrm{t}$ 依存性 $\mathrm{O}$ : 室内放置試料 0 : 室外放置試料

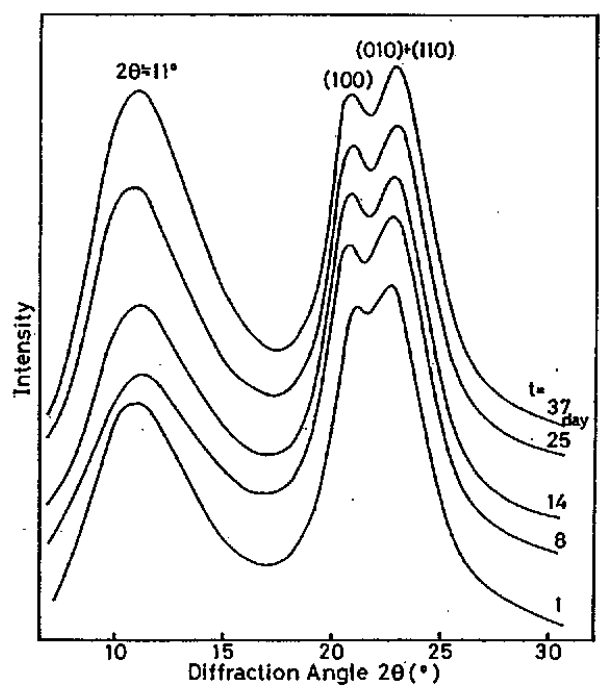

図 4 室内放置試料の $\mathrm{X}$ 線回折強度曲線の経時日数 $\mathrm{t}$ 依存性

折から得られた結晶配向度も同様の㑯向で示す．例 えば放置 0，1，4，および14日において CO は 88\%，

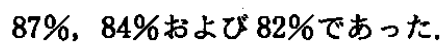

以上のことから, 結晶領域内部の超分子構造は経 時的に, 結晶は大きくなり, その結晶の完全度は高 くなる. また配向度は小さくなる.そしてこれらの 変化は室内より室外放置の方か顕著である.

結晶領域内部の不完全度の量的変化を検討するめ たに, 図 4 に示したX 線回折強度の回折角 $2 \theta=11^{\circ}$ と $23^{\circ}$ におけるピーク強度比の経時変化を図 6 に示 す.この比は隣接する分子鎖間の水素結合の方向の 乱れ，あるいは不完全結晶部の量を表すパラメータ 一とみなせる，室内放置の場合，約25日でこの強度

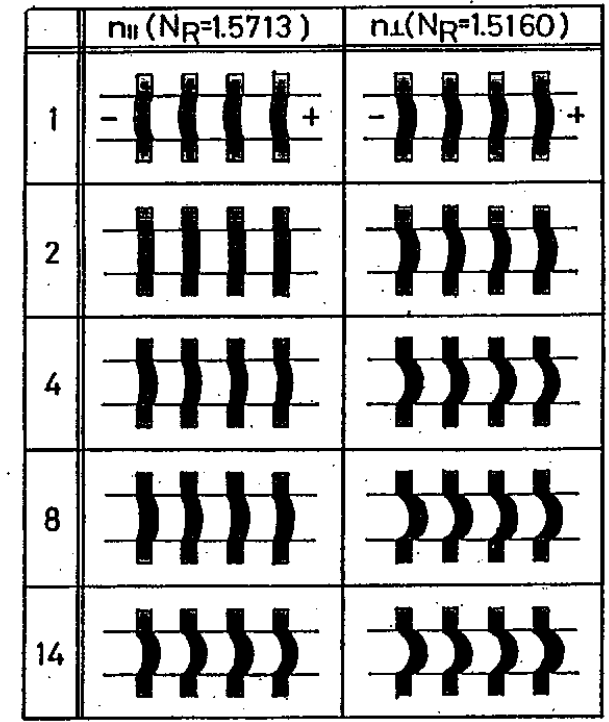

図 5 干涉顕微鏡の干涉縞の経時日数 $t$ 依存性 $N_{\mathrm{R}}$ は浸液の屈折率

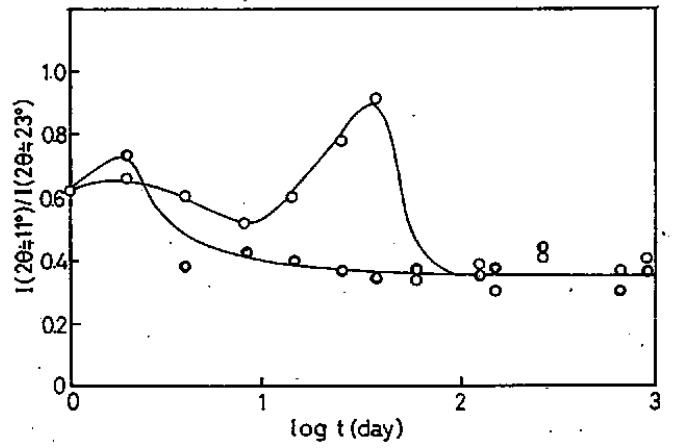

図 $6 \mathrm{X}$ 線回折強度の回折角 $2 \theta=11^{\circ}$ と $23^{\circ}$ のピーク強 度比の経時日数 $t$ 依存性

$\mathrm{O}:$ 室内放置試料 : 室外放置試料

比が最大になり，室外ではより短時間 (2〜3 日) の うちに最大になると予想される。この $2 \theta=11^{\circ}$ にお けるピーク強度比が大きくなる原因を明らかにする ため, ナイロン66縕維原系を湿度の異なる雾囲気 下，あるいは X 線回折湘定時間中湿潤状態におい た場合の X 線回折強度曲線を調べた結果を図 7 に 示す.

水分率の增加によって $2 \theta=11^{\circ}$ のピーク強度が大 幅に増加することが分かった． 相対湿度 $100 \%$ の試 料を $190^{\circ} \mathrm{C} \times 15 \mathrm{~min}$ 間定長状態で乾熱処理を行うを （図中波線）ピーク強度は大きく減少する。すなお ち, $2 \theta=11^{\circ}$ と $23^{\circ}$ の強度比は, 水分の吸脱着によ。 て大幅に増減する. 従って $2 \theta=11^{\circ}$ の X 線回折で特 徽づけられる不完全結晶部は, 水分子の存在によっ 


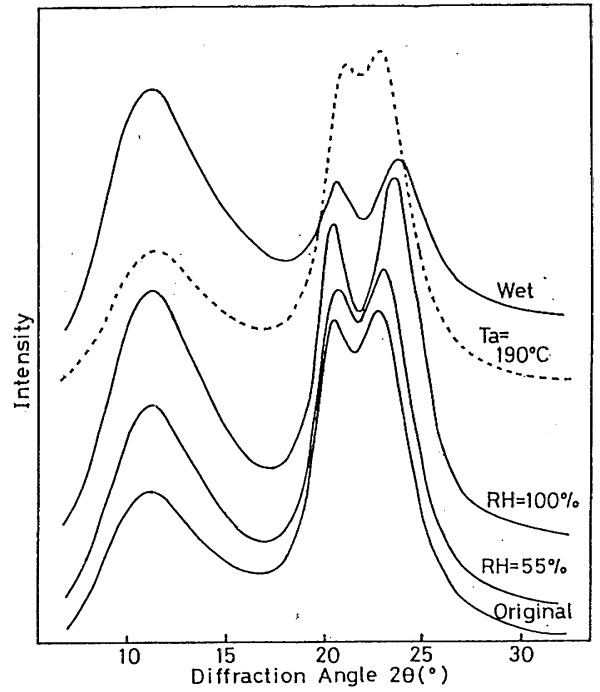

図 7 ナイロン66繊維の水分率による X 線回折強度曲 線

て顕著に現れる．それらの変化は室内より室外の方 が著しく加速され, 不完全結晶部の経時変化は水分 が強く影響している.

ナイロン66の結晶構造では，平面ジグザグ状の分 子鎖は $\mathrm{NH}-\mathrm{O}$ 型水素結合により結ばれてすだれを 作り, ac 面に平行に van der Waals 距離を隔てて 重なっている.このすだれの並び型に $\alpha$ 型と $\beta$ 型の 2 種類がある. 本報告でのナイロン66の結晶構造は 安定な $\alpha$ 型結晶構造ではなく, 不安定な $\alpha$ 型結晶構 造であるため, 水分の影響によって $\alpha$ 型と $\beta$ 型の中 間構造の結晶構造を形成し, 経時日数によって不安 定な結晶構造が安定化すると考えられる.

次に無定型領域の構造変化について検討した.

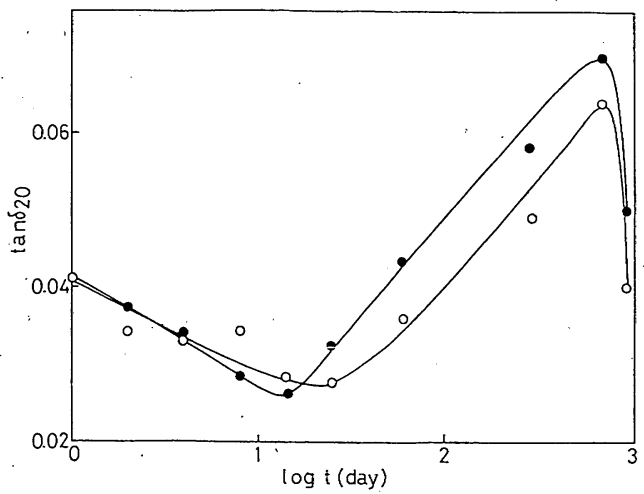

図 $820^{\circ} \mathrm{C}$ における $\tan \delta$ 值 $\left(\tan \delta_{20}\right)$ の経時日数 $t$ 依存 性 $\bigcirc$ : 室内放置試料 : 室外放置試料

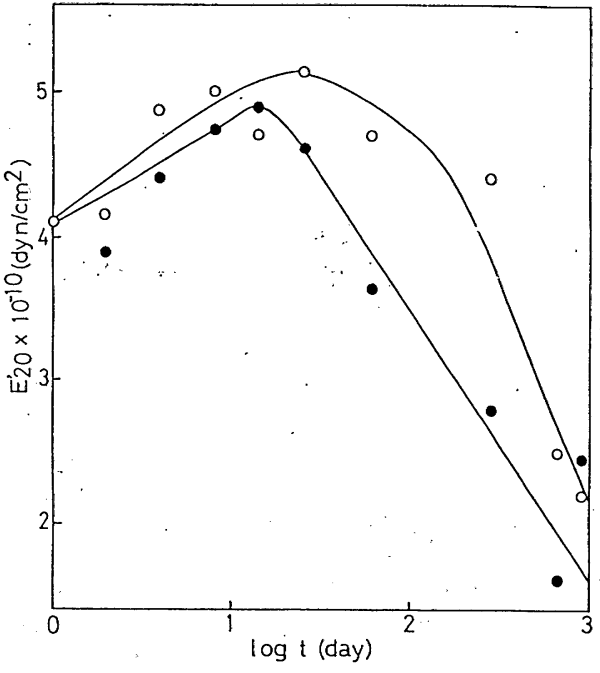

図 $920^{\circ} \mathrm{C}$ における動的弾性率 $E_{20}^{\prime}$ の経時日数 $t$ 依存 性

$\bigcirc$ : 室内放置試料 $\bigcirc$ : 室外放置試料

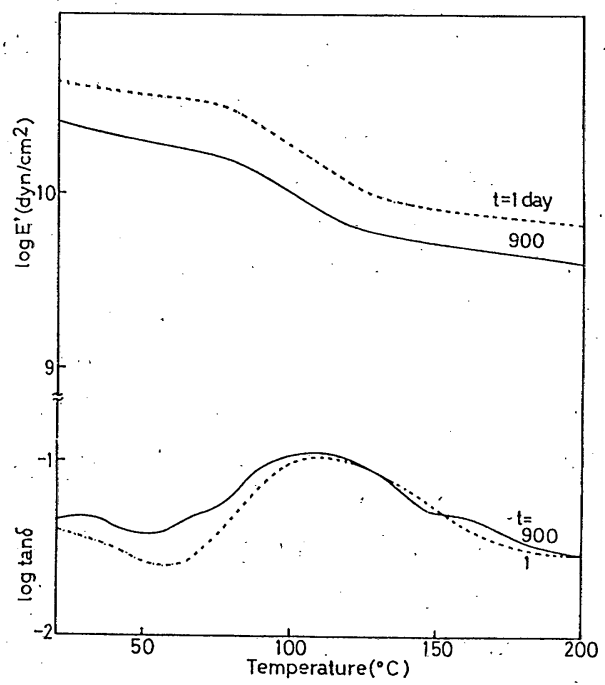

図10 動的弾性率 $E^{\prime}-T$ 曲線および $\tan \delta-T$ 曲線の 経時日数 $t$ に及ぼす変化

$20^{\circ} \mathrm{C}$ における $\tan \delta$ 值 $\tan \delta_{20}$ (図 8) は，15日ぐらい 経過すると最小となり，約700日で最大となり，その

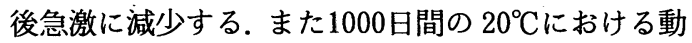
的弾性率 $E_{20}$ (図 9) は, 15 20日で最大となり, そ の後, 単調に減少する. 1 日, 900 日経過後の $E^{\prime}-$ $T$ 曲線および $\tan \delta-T$ 曲線（図10）から，900日経 過後の $110^{\circ} \mathrm{C}$ 付近の $\tan \delta$ のピーク值はわずかに増 加し, ピーク温度は低下する. また $150^{\circ} \mathrm{C}$ 付近に新た なピークが出現し, $\tan \delta-T$ 曲線は幅広くなる. 図 11 に室外放置日数を変化させた際の結晶完全度と不 


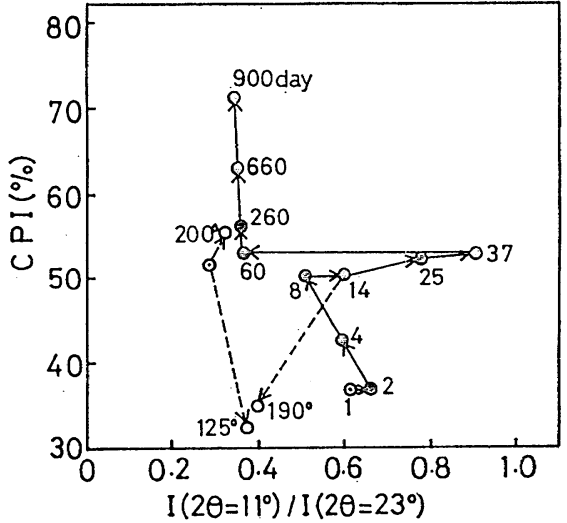

図11 室内放置日数の異なる試料の結晶完全度 $C P I$ と 不完全結晶の存在量を反映する X 線回折強度比 I $\left(2 \theta=11^{\circ}\right) /\left(2 \theta=23^{\circ}\right)$ の関係.

図中の $190^{\circ}, 200^{\circ}, 125^{\circ} \mathrm{C}$ は熱処理温度, その他 の数字は放置日数. ○は熱処理前, ○は熱処理 後を意味する.

完全結晶の存在量を反映する $\mathrm{X}$ 線強度比 $\left(2 \theta=11^{\circ}\right.$ $\angle 2 \theta=23^{\circ}$ ) の関係を示す (図中の数字は放置日数). 破線の変化はそれぞれの温度で熱処理（5min 間, 定長）した際の変化を示す.

$190^{\circ} \mathrm{C}$ おび $125^{\circ} \mathrm{C}$ での熱処理に伴って結晶の完 全度を示す $C P I$ は減少し, $200^{\circ} \mathrm{C}$ 熱処理でわずか に増加する. 一方, 経時変化の方向は CPI の増加す る一方向である．また不完全結晶の相対的存在量を 示す $I\left(2 \theta=11^{\circ}\right) / I\left(2 \theta=23^{\circ}\right)$ の值は熱処理によ ってある一定値 (約0.4) に近づくのに対して, 経時 変化ではこれは減少, 増加, 減少の複雑な変化をし ながら一定值（約0.4）に近づく.すなわち, 結晶領 域と不完全結晶領域の経時変化の方向は, 熱処理の 際の変化の方向とは一致しない。

図12に $(\tan \delta)_{\max }$ と $T_{\max }$ の経時変化および熱処理 による変化を示す. $(\tan \delta)_{\max }$ は経時的に, また熱処 理に伴ってあ増加する. $T_{\max }$ は経時的に，また熱処 理に伴って低下する.すなわち, 無定型領域内部の セグメント環境の経時変化は熱処理の際の変化と定 性的に一致する. 無定型領域の構造は, 時間の経過 によってまず分子鎖は緊張状態になり（ $T_{\max }$ の上 昇, および $E_{20}$ の増加より推定), その後緩和する ( $T_{\max }$ の低下, $E^{\prime}{ }_{20}$ の減少). また, およそ900日経過 する之分子鎖の充填状態の密な部分が新たに出現す ることが図10における $150^{\circ} \mathrm{C}$ 付近の $\tan \delta$ の肩の出 現から推定される.これらの変化は室内より室外の 方が顕著である，室外の方が顕著なのはおそらくは 温度変動幅および湿度変動幅が室内に比べて大きい

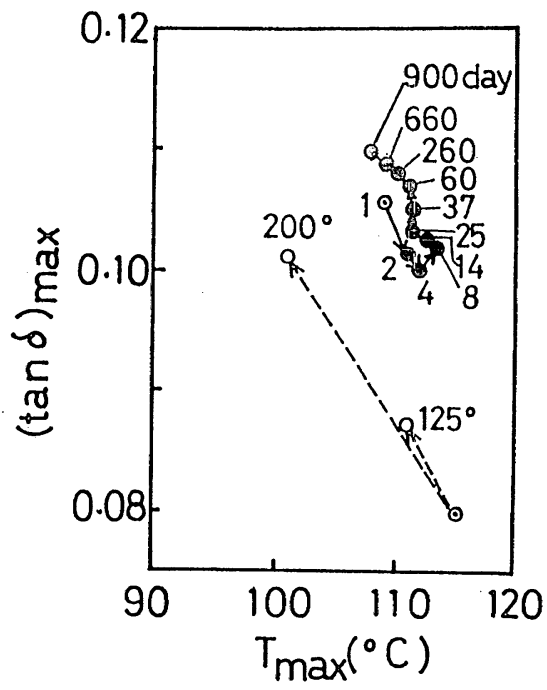

図12 室内放置日数の異なる試料の $(\tan \delta)_{\text {max }}$ と $T_{\text {max }}$ との関係

破線は熱処理変化を表す

図中の数字および@と○の意味は図11と同様で ある.

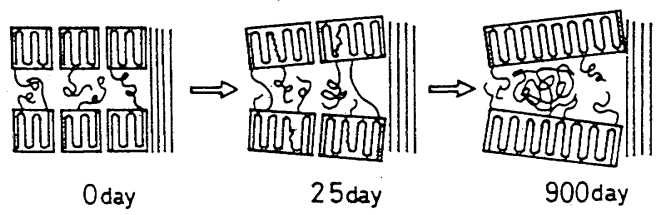

図13 ナイロン 66 繊維の超分子構造の経時変化の模式 図

図中の数字は経時日数, 模式図の直線部分は伸 びきり分子鎖, 長方形は結晶領域, 乱雑に絡み 合った曲線は無定型領域の分子鎖を表す。

ためであろう。

最後に, 結晶および無定型領域の結果から推測さ れるナイロン66繊維の超分子構造の経時変化を模式 図に示すと図13のようになる．繊維はフィブリルお よびミクロフィブリル構造で構成され，ミクロフィ ブリルは不完全結晶部む含めた折りたたみ鎖結晶領 域と, 伸びきり分子鎖と, それ以外の無定型領域で 構成されている6 ${ }^{6}$.このような構造をしていた緎維 は，室外放置で25日ぐらい経過すると結晶は成長 し, tie 分子鎖の緊張は高まる.また主に水分の影響 を受け, 結晶領域内部の不完全結晶は一時的に大き く乱れる. その後, 経時日数が経過するにつれてさ らに結晶は大きく成長し続け, 結晶完全度も増加す る. すなわち初期の不安定な $\alpha$ 型結晶は水分の影響 を受け， $\alpha$ 型と $\beta$ 型の中間状態の結晶構造を形成 
し，その後安定な $\alpha$ 型結晶構造になる. 無定型領域 内部の分子鎖の緊張状態は緩和され, 一部の tie 分 子鎖が切れ, cilia $^{7)}$ 一移行し, 分子鎖の充填密度 の分布は幅広くなり，無定型領域内の分子鎖の一部 は元の試料より密な充填をした部分を形成すると考 えられる.

\section{4. 結 言}

ナイロン66繊維の放置条件に伴う超分子構造, 特 に結晶および無定型領域内部の分子鎖の凝集構造の 経時変化について検討した結果, 結晶領域内部の超 分子構造は経時的に, 結晶は大きくなり, その結晶 の完全度は高くなる.

無定型領域の構造は，まず無定型領域内部の分子 鎖は緊張状態になり,その後緩和され, tie 分子鎖は cilia $^{7}$ 一と移行する．そして分子鎖の充填密度の分 布は幅広くなり，無定型領域内の分子鎖の一部は元 の試料より密な充填をした部分を形成すると考えら れる.

\section{参考文献}

1）中山暢三, 上出健二, 真鍋征一, 原正勝；織学誌，33， T280 (1977)

2）上出健二, 真鍋征一, 原正勝, 中山暢三；織学誌, $31, T-1$ (1978)

3) D.F.Dismore,W.O.Statton;J.Polymer Sci., 31, 133(1966)

4）吳祐吉, 久保輝一郎；工化, 39，929（1936）

5) H.W.Starkweather,J.F. Whitney,D.R.Johonson;J.Polymer Sci.28, 715 (1963)

6)たとえば, A. Peterlin ; Colloid Polymer Sci.,253, 809 (1975)

7）たとえば織維機械学会編, 織維工学(II), 日本瀻維機械学会, 1983, 245頁 